\title{
Media Literacy: Ukrainian Perspective
}

\author{
O. A. Borysenko, S. S. Vysotska \\ Borys Grinchenko University, Kyiv, Ukraine \\ Corresponding author. E-mail: cborysenko@gmail.com; solomiiawysocka@gmail.com
}

Paper received 27.01.18; Revised 01.02.18; Accepted for publication 05.02.18.

https://doi.org/10.31174/SEND-PP2018-154VI64-03

\begin{abstract}
The development of new media and rapid global technicalization and computerization of all spheres of human life - business, education, culture, etc. - make digital and media literacy proficiency an indispensable skill for everyone. In Ukraine, despite the urgent requirements of the time, media education is still fragmented and is implemented sporadically, and there is no integration of the efforts of teachers-innovators into a unified effective system of media education which is to play an indispensable role in creating civil society. Studying and analyzing experience of more advanced countries in the area of media education, means and ways of making media education really effective, not just one more subject for pro forma which school and university students do not consider interesting and useful, should become the focus of future research and discussions.
\end{abstract}

Keywords: biased information, digital literacy, information, media education, media literacy, propaganda, propaganda immunity.

Introduction. The development of new media and rapid global technicalization and computerization of all spheres of human life - business, education, culture, etc. - make digital and media literacy proficiency an indispensable skill for everyone. "Today, media literacy is as central to active and full citizenship as literacy was at the beginning of 19th century," as it was remarked by V. Reding, ex-European Commissioner for Information Society and Media [30]. Only when people have acquired it, they are able to use the benefits and opportunities offered by progress and innovation in the new media environment: to gain extended chances for interaction with others, for receiving and producing information, for getting better jobs and for professional development. They will have access to the world cultural heritage and traditions of democracy, and will be able to promote democratic values. With the increasing use of digital technology in all spheres of life, media literacy has become "a necessary part of active citizenship and is the key to the full development of freedom of expression and the right to information. It is therefore an essential part of participative democracy and intercultural dialogue", the EU Commission on Education and Training declared [37, p. 14].

The strive of Ukraine to become an advanced information and democratic society of equality and social cohesion within the European community has led to a lot of dramatic changes that have been taking place here. Chosen the democratic way of development, the country has been initiating radical reforms in practically all spheres of life. However, change is a slow process; it does not come overnight, and it is quite natural that it may cause resistance. So, on the way forward there may be confusion and disappointment of some part of people. Besides, at present, the process of the implementation of changes and reforms is complicated by the war, the so-called "hybrid war" unleashed by the neighbouring country against Ukraine.

This kind of war is characterized by military operations combined with a wide spectrum of political, economic as well as information and propaganda acts which, as a rule, start the war and accompany military operations during the whole period of it. Those disinformation and propaganda projects and activities are directed against the population of Ukraine and people the world over with the aim of weakening the country, discrediting the Ukrainian government and its Armed Forces and depriving the state of international support as well as the support and trust of Ukrainians.

Media environment creates a specific media reality around each person; it is under the influence of this media reality that the person's education, culture, worldview, and values are formed [45, p. 1]. Despite the fact that disinformation presented by the enemy is not very sophisticated as far as its form and content are concerned, it finds its audience and sometimes hits the target. Opinions of the population of the South and the East of Ukraine about the causes of the war are a bright example: $33 \%$ of the population there believe that the government of Ukraine is guilty of the war, and only $33 \%$ accuse the aggressor. This is in spite of the fact that the war is being held on the Ukrainian territory, with a considerable part of the Donbas occupied by and with the Crimea annexed. More than that, 24 hours seven days a week Ukrainian mass media present information about the situation at the front. $16 \%$ of Ukrainians accuse Western countries, the USA and the EU of inciting the war, with some people sincerely believing that the NATO soldiers are actively participating in the battles, with a lot of Afro Americans among them. More than $37 \%$ think that it is difficult to say by whom the war was started. The data is taken from the survey conducted in the East of Ukraine in July, 2017 (https://hromadskeradio.org/news/2017/07/09/hto-vynen-uviyna-na-donbasi-rezultaty-socopytuvannya). There are Ukrainian citizens who do not follow the situation in the East at all and continue living their usual life though there are victims of the war everywhere in the country, those killed, wounded, and IDPs. Some people praise the dictatorship of Stalin despite the Great Terror and other campaigns of political repressions in the Soviet Union; there are also Ukrainians who would like to live in the aggressor country; and there are young people who, after having attended the compulsory university course of media education, sincerely believe that Ukrainian singers, actors and actresses have the right to go to the aggressor country to entertain them there and to earn money, with the war being no obstacle.

The question arises about the origin of such a radical discrepancy in the mentality of Ukrainian citizens and why that catastrophe in the heads happens - the people surveyed live in the same cities and towns, walk along the same streets; they have access to information: they watch the same TV programs, read the same newspapers, and surf the same internet. It seems that there are quite a few people who are simply media illiterate as they cannot perceive and evaluate information; they take what is on the surface and do not apply any efforts to concentrate, to filter the information and to analyze it. In this case the problem lies in the absence of appropriate media education and media literacy which has not been developed as a result of it. That is why there is 
urgent necessity to intensify media education development in the country in order to make people resistant to the information aggression and destructive propaganda [40, p. 1]. Media literate citizens, "an informed electorate is the cornerstone of democracy" and teaching students to be good citizens in a democratic society is the goal of media literacy [39, p. 4], making media education one of priorities of the whole system of education, especially of Ukrainian education system, and especially at the moment. On the one hand, due to modern technology, media are an easily and totally accessible, invaluable source of formation. On the other hand, modern technology offers profitable opportunities for misinformation, unwanted surveillance, abuse of the vulnerable and infantilization of public discourse [37, p. 2]. Thus, people, namely the young generation, are to have persistent moral values to be able to critically assess the information obtained, to tell the truth from a lie, and to distinguish useful and valuable information from trash and harmful staff.

The objective of the article is to analyze the state of media education and literacy in Ukraine, to observe the existing experience of more advance media literate countries, and to outline the tasks facing Ukraine in the area of media education

Literature review. Though "media education" and "media literacy" came to this country a considerable time ago with the advancement of modern technology, it is understandable that they are gaining momentum and should be paid much attention to just at present.

Media education process and its final product - media literacy were introduced and defined by the UNESCO in 1982. They were described, discussed, and developed in international documents at conferences in Grunewald (1982), Toulouse (1990), Vienna (1999) and Seville (2002). The work has been continued by the Council of Europe, in the European Charter of Media Literacy and by public media regulation institutions [37, p. 10-17].

Theory and practice of media education and media literacy have been in the center of modern pedagogical discourse and analyzed in quite a number of publications and conference presentations; they have been developed by participants of conferences and workshops, media projects and programmes $[23 ; 24 ; 35 ; 36 ; 37 ; 41 ; 42]$.

Theoretical foundations of media education and literacy were laid down and analyzed by D. Buckingham, O. Fedorov, S. Livingstone, L. Masterman, D. Rowe and a lot $\mathrm{f}$ other researchers $[2 ; 3 ; 4 ; 7 ; 19 ; 21 ; 32 ; 47]$. L. Naidenova [43] devoted her works to psychological and pedagogical aspects of media education. The syllabus of Media Education as an academic subject was presented by Professor R. Hobbs [11]. Practical recommendations for administering media education were given by D. Frau-Meigs [8]. A lot of publications are devoted to Western experience and good practices, achievements and challenges $[16 ; 17 ; 20 ; 27 ; 39]$. The situation with media education and media literacy in Ukraine was investigated in the report presented by Internews Network [12]; the problem has also been in the focus of attention of the National Ministry of Education and Science as well as the National Academy of Pedagogical Sciences, the latter having adopted the Concept of Administering Media Education in Ukraine [41] and published a textbook for those who deal with media education, teachers and students of various education levels [43].

Discussion. There are different approaches to media edu- cation and consequently to media literacy. Some people associate it with the ability to critically evaluate information, to produce and share it; others concentrate on the ability to use various modern technology equipment and gadgets. However, the majority of media educators see their job, first of all, as guiding students to think critically about the information presented to them through mass media sources.

Technical skills how to use smart phones, surf the internet, and become users of social networks are mastered by people more or less easily, especially by younger users, and very often without special training, just by observing and imitating others or by following instructions. At the same time, critical perception of information presented may be challenging, and thus there arises the problem of developing media literacy though media education. People may be quite experienced readers and can write without grammar mistakes, but they may not understand the content; they are not able to write a cohesive logical text; they cannot decode the artistic language of literature. There are quite a few people who prefer straightforward, linear information and rather rude, non-sophisticated pop culture. Those people are totally inexperienced in perceiving information, analyzing it, understanding what is true, and what is lies and manipulation. Some researcher even claim that media illiteracy leads to functional illiteracy when illiteracy prevents people from fulfilling their professional duties properly as it causes deep impairments in mechanisms of thinking, attention, and memory [46].

On the other hand, media literacy is not only understanding and evaluating of information perceived and combatting counterpropaganda and misinformation. It is a positive and creative approach as well; it is protection and promotion of positive creativity, good examples, growing sensitivity to communication, and active participation in global civil society. The European Union emphasizes the motion of media education focus from protection to promotion and there are three basic models which stand out. "One of them is dominated by the objective of protection against possible harm from the media, a model in which mistrust and suspicion of the media are evident. In the second model, promotion, mistrust and suspicion are replaced by the objective of taking advantage of the benefits offered by new media. Finally, the third model is more eclectic, combining protection and promotion, and adding creative production" [37, p. 33-34].

Thus the question arises what the concept of this "new" literacy or new communication environment is. The crucial pinpoint is whether this new form of literacy is really new and what the differences are between it and the literacy in the traditional sense - whether media literacy is closely connected with literacy, ability to read and write. Researchers stress that "today, as we witness a further major shift in information and communication technology (ICT), a new form of literacy is emerging, uneasily termed computer literacy or internet literacy" [19, p. 1]. "The hugely significant skills of reading and writing have been augmented by the alsosignificant skill of 'reading' audiovisual material" [ib.]. This "new" literacy is considered by reseachers as a multidisciplinary phenomenon and comprises literacy, culture, media education, human-computer interaction, and social studies of technology $[14 ; 17 ; 39]$.

Thus, it may be stated that the content of the term "literacy" has been considerably extended. Radical changes, which have been taking place in the area of communications, in- 
clude opportunities in self-editing, access to sources of information, interaction, searches, etc., with net users having an extended and sophisticated system of various tools and devices to explore and use the new communication environment: blogs, video networks, podcasting systems, twitters, viber, search engines, specialized systems for plagiarism search, wikis, clouds, professional networks, social networks, homepages, moodles, etc. All of them make it possible for users to interact, creatively cooperate, share and distribute their products, new knowledge, and information. In other words, the appearance of new tools changed the way people communicate giving them new opportunities and creating "new intellectual, semiotic, communicative and cultural climate, which has had a marked effect on both personal, work-related and social development" [37, p. 5]. The comparison of electronic media of mass communication and the new digital media is presented below (adapted from $[37$, p. 5]):

\section{Old Electronic Media (Mass Communication)}

Autonomy of each form of media
Centralised circulation
Passive consumption
Centralised professional production
Languages separated by media
Static broadcast-consumption
Creation of extensive audiences
National circulation
New Media (Digital Media)
Media convergence
Communication-network
Interactive consumption
Decentralised social production
Multimedia languages
Mobile broadcast-consumption
Creation of communities
Global circulation

Thus, it is impossible not to agree with S. Livingstone who claims that today's media are "socially diversified (rather than mass), technologically converged (rather than distinct) and interactive (rather than one-to-many, with producer and receiver separate). ...Hence, literacy seems to do the work required here: it is pan- media in that it covers the interpretation of all complex, mediated symbolic texts broadcast or published on electronic communications networks; at the same time, because historically it has been tied to particular media forms and technologies, literacy foregrounds the technological, cultural and historical specificity of particular media as used in particular times and places" [19, p. 2-3]. It means that, to be able to respond to the challenges of the new communicative environment, people should be media literate, capable to interpret information autonomously and critically [37, p. 3].

R. Jackson emphasized that "meaningful learning happens when students try to make sense out of the world by filtering new information through their own existing knowledge and schemas. Meaningful learning occurs when students create their own knowledge, concepts, rules, hypotheses, and associations from personal experiences. Our job is to help our students find their own voices and develop their own understanding of the subject matter" [13, p. 17]. In other words, the central goal of media literacy education is to develop students' ability to think for themselves [39, p. 4].
On the basis of the above, media literacy may be identified as the ability of a citizen to access, analyse, evaluate, and produce information in a variety of forms for specific outcomes $[1$, p. $1 ; 6$, p. $5 ; 19$, p.3; 10, p. 6], the ability allowing to interpret and to decode audio-visual media. As a consequence, it is possible to speak about four components or competences which media literacy comprises and which should be developed while mastering media literacy in the process of media education. These competences are: ability to access information, ability to analyze and evaluate it, and ability to create content. So, media literacy deals with the whole spectrum of media convergence [19, p. 11] and encompasses other forms of literacy: reading and writing literacy, audiovisual literacy, and digital or information literacy, with reading, writing and understanding at the foundation of it.

The European Charter of Media Literacy [38, p. 21] presents a more detailed approach and states that there are seven areas of competences (or uses) related to "media literacy:

- Use media technologies effectively to access, store, retrieve and share

content to meet individual and community needs and interests;

- Gain access to, and make informed choices about a wide range of media

forms and content from different cultural and institutional sources;

- Understand how and why media content is produced;

- Analyse critically the techniques, languages and conventions used by the

media, and the messages they convey;

- Use media creatively to express and communicate ideas, information and opinions;

- Identify, and avoid or challenge, media content and services that may be

unsolicited, offensive or harmful;

- Make effective use of media in the exercise of democratic rights and

civil responsibilities."

Thus, following A. Parola, four main areas within the framework of media competences may be generalized and distinguished: "(1) reading the media: the ability to read media and decode media languages; (2) writing the media: the capacity of producing media texts and of using digital instruments for creative purposes; (3) critical understanding and evaluation of the media: the complex attitude of observing media contents and objects from a distance; (4) media consumption awareness: the capacity of creating awareness as to choices in the consumption of media understanding the explicit and implicit media messages in different situations" [27, p. 92]. So, the above are the skills which are to be covered by media education syllabus and developed in the process of teaching and learning.

"Evaluation is crucial to literacy: imagine the World Wide Web user who cannot distinguish dated, biased or exploitative sources, unable to select intelligently when overwhelmed by an abundance of information and services. Being able to evaluate content is no simple skill, rather critical evaluation rests on a substantial body of knowledge regarding the broader social, cultural, economic, political and historical contexts in which media content is produced" [19, p. 5]. Thus, specific filters to select material found, read, and 
distributed should be formed on the basis of criteria of cultural quality, ideology, market pressure or professional production values while teaching critical media literacy when providing access to ICT resources. As a result there appears some "tension between a positive approach to education-asdemocratization and a defensive or paternalist approach to education-as-discrimination" [op. cit., p. 4].

As far as media production is concerned, it may be noted that new technology presents ample opportunities for people to write and to produce texts, written or symbolic, much more than in the past when people were more receivers of information than its producers. Today people of practically all generations have access to and are active users of emails, social networks, web-cameras, and content producing software. Another argument in favour of teaching media content production within the framework of media education is that people understand better the techniques and conventions of media if they experience creating media themselves. What is more, it should not be forgotten that citizens of a democratic country should have the right to self-expression $[10$, p. $6 ; 15$, p. XI-XXIX; 20, p. 71; 31, p. 21; 33, p. 14-25]. At present, "content creation within media literacy programs requires further research to establish the relation between reception and production in the new media environment, together with further clarification of the benefits to learning, cultural expression and civic participation" $[19, \mathrm{p} .5]$.

Thus, new technology significantly extends media literacy including the ability to interact, to read multimedia texts, to deal with hypertextuality, to understand visual aesthetics, etc. in contrast with traditional linear, hierarchical, logical and consequential text $[5$, p. $118 ; 18$, p.7-8; 22, p. 169-170;25, p. 4].

Media education is not the exclusive prerogative of the school or formal teaching. The context of media education is much broader. It is personal life of individuals and interaction with others, family setting, institutional spaces, media context, and social life - social activities and various campaigns.

Media literacy and education are paid much attention to in Europe today, and the European Union has initiated projects to encourage the development of media education. Media literacy was included in the set of competences for life-long learning and is defined as "the confident and critical use of Information Society Technology (IST) for work, leisure and communication, it is underpinned by basic skills in ICT: the use of computers to retrieve, assess, store, produce, present and exchange information, and to communicate and participate in collaborative networks via the Internet" [29]. The importance of promoting greater pedagogical awareness among educators and teachers regarding the aims and ways of implementing media education is also underlined [27, p. 94]. The promotion of already existing practices in the field of media education, attracting teachers to the design of new ME materials, and development of recommendations concerning good practices should not be ignored either.

One of the examples is the research project EU Kids (http://www.eukidsonline.net) which focuses on the protection of minors against digital media risks (scarcely reliable content; connections with strangers, privacy, cyberbullying and cyberstalking; illegal downloading, gambling etc.), and, at the same time, empowerment of them concerning their relationship with media (accessing information resources, participating in social networks and interest groups, exchang- ing information; forms of civic engagement and content creation activities [9, p. 48-49; 27, p. 90; 34, p. 26-27].

The project OnAir, a European project on Media Education funded by the European Commission, may serve as another example. It was a two-year project launched in six European countries - Belgium, Bulgaria, Italy, Lithuania, Poland, and Romania - to collect, document, and develop media education practices across Europe [27, p. 1].

Another publication of the European Union is devoted to good practices in 4 media education leaders: Finland, Sweden, the United Kingdom, and the Netherlands - Media Education in Four EU Countries: common problems and possible solutions. Formal media education in Finland starts in a kindergarten. An example of Finnish achievements in media education is computer application - a complete educational programme Angry Birds. Based on the Finnish National Curriculum for Kindergarten and developed by the Department of Teacher Education at the University of Helsinki, it is intended to help young children in the context of early learning in maths, language, music, and art [23, p. 1217]. At school, media education is not taught as a separate subject. It is usually taught as part of mother tongue education. The curriculum states that "pupils must improve their media literacy so that they can properly interpret the various messages that they receive from the media, can estimate the background and function of those messages, and can understand how those messages can influence individuals and society as a whole. Attention is also devoted to netiquette and to the responsibilities that media production involves" [op.cit., 14].

In the United Kingdom media literacy is not a specific subject, although the media is taught as part of mother tongue (i.e. English, Welsh or Irish) learning and as part of Citizenship. "The United Kingdom has a special position, globally speaking, as regards media literacy because "media studies" has been taught at British schools since the 1970s. This special optional subject is given at secondary schools for pupils aged 14 to 18 . This long tradition means that schools and teachers have built up tremendous expertise in the field of media education over several decades. Good teaching materials are available" [op.cit., 24]. British Media Literacy teachers claim, "We have one of the longest traditions where media education is concerned. We have exams in media studies and teachers with a great deal of experience because this subject has been taught for decades now. When media studies was first taught here as a separate school subject, hardly any other countries were doing so. The courses concerned popular culture, specific media, the institutions within the media landscape, types of audiences, and the politics of representation. That constitutes an exceptional pedagogical and didactic tradition" [ib.], with creating films, teaching materials, and lesson packages that can be used during lessons.

The processes taking place in the world do not eliminate Ukraine where the Concept of Media Education (40) was adopted in 2010 and upgraded in 2016 as there is an urgent need to guide the influence of media on Ukrainian citizens, in particular, the young generation, to develop their positive and creative attitude to reality, to establish the system of real values, to protect them from media manipulations and negative influence, and to develop immunity to the influence of low-grade and harmful media production. The concept is based on the UNESCO media education recommendations 
of 2007 (June 22, Paris) and The European Charter of Media Literacy of 2009 [38]. The Concept comprises three stages:

I Experimental (2010-2016): raising awareness of the necessity of developing media education system in the country, carrying out media education experiment; development of curricula and syllabuses for school media education course, training of media teachers and psychologists.

II Acceleration of media education and standardization of the requirements (2017-2020): discussion of the results obtained, SWAT analysis, development of education materials, mass training of teachers and establishment of teacher upgrading system.

III The further development of media education and its mass introduction (2021-2025) in education establishments, analysis of existing practical problems, experience exchange, and the development of required equipment [40, p. 8-10].

The Concept is aimed at carrying out a large-scale national experiment of creating holistic system of media education starting with schools and finishing with universities, attracting budget money, initiating wide public support and international cooperation in the field, with the National Academy of Pedagogy being the coordinator of the process. Thus, the main tasks of media education in the country are as follows [op. cit., 4-5]:

- Formation of media immunity to counteract aggressive media space, formation of media awareness;

- Reflection and critical thinking, informed consumption of media products, orientation in media space and ability to assess the information presented;

- Ability to create media products to interact within various media nets and communities;

- Ability to employ new information communication technology and resources;

- Respect for national traditions and culture;

- Priority of moral and ethical values and appreciation of human, nature, arts, etc.

As a result, media education and consequently media literacy should become an important integral part of political culture of the Ukrainian society.

Thus, national media education faces the following tasks, in accordance with the Concept, which are identified as follows:

- The development of school education, the design of media education curricula and syllabuses, integration of media education issues in the syllabuses of other subjects, arrangement of selective courses on media education and various study groups to develop photo, video animation and other skills as creative media education;

- Special training of media education teachers;

- Conduction of research in the field of media education under the auspice of the National Academy of Sciences;

- Arrangement of various events, festivals, contests, projects, and programs to contribute to the development of media culture and media education.

The above should be implemented within the framework of preschool education, school education, extracurricular activities, within the framework of tertiary education, in families, and for adults in the form of life-long education and development with the help of modern information and communication technology and high-quality media products [op. cit., 6-7].

The Analytical Report on the Results of Complex Study conducted by Internews Network during 2014-2016 and commissioned by Ukrainian Media Project (U-Media Program) may be used as an instrument to monitor and assess the results of the implementation of the Concept, and the achievements and challenges of media education in Ukraine. The Project faced the following "tasks:

- to inspect methods and means of media education implementation;

- to study available and needed resources;

- to register and evaluate new developments and changes in media education / media literacy (ME/ML) implementation process;

- to determine and analyse challenges faced by secondary school personnel when teaching media education course;

- to analyse the effectiveness of the existing methods of media literacy teaching" [12, p. 3].

In general, the results obtained showed that Ukrainian schools lack teachers who are trained to teach media literacy. One more thing the success of education depends on is motivation of school management who allocates academic hours for teaching media education. Then, the school should have appropriate equipment for teaching the subject.

At Ukrainian schools Media Education is taught under various names: "Media Culture", "Media Literacy", "Media Education," etc. It happens that teachers specializing in other subjects, Literature, History, Social Sciences, Math, Computer Science, school directors, psychologists, etc. teach the subject. Media education is taught in diverse formats, as compulsory lessons, elective courses, or is integrated into other subjects. It is evident that if a compulsory subject is supported by extracurricular activities, the result will be sounder. So, schools are to arrange extracurricular courses and activities.

Despite the fact that a lot is still to be done, teaching Media Literacy is a dynamic, developing process: "media education teachers have acquired new experience, have considerably improved teaching techniques and developed new ideas related to elaboration of practical assignments for pupils, as well as to ways of encouraging and engaging the widest possible audience in studying the subject. The most specific accomplishments of last years include successful integration of media education in different school subjects, inclusion of the elements of media literacy course in the educational process, spread of media education teaching for different age audiences - starting with junior school and up to the seniors. Media literacy teachers are open to new ideas, exchange of experiences and practical achievements, and consider media education course to be one of the hallmarks of modern Ukrainian school system" [op. cit., 8]. The Order of the Ministry of Education and Science of Ukraine on Compulsory Media Education Course in secondary schools could guarantee success of media education implementation in Ukraine. And, as a result, there are positive examples and achievements: media education projects for kids are developed in Ukraine too. For example, in summer 2017, children from frontline regions of the Donbas, while being in a recreation camp Yellow Bus (film camp "Zheovtyi Avtobus"), mastering the language of the cinema and its expressive means, made films about travelling across time. Under the guidance of movie-making experts, children developed scripts, shot and created films. The presentation of the films produced took pace in one of Kyiv movie theatres.

Conclusion and problems for future research. In different countries of the world including Ukraine media educa- 
tion has become an indispensible part of youth education and media information policy as it is closely connected with the development of democracy and civil society.

Media education in Ukraine has yet to obtain popular support, since teachers and parents want their pupils and children to be more computer literate than to be media literate [16, p. 1]. At media education classes more attention is paid to the content of books and articles, less - to the information evaluation. When IT classes are held, teachers think that students are more computer-minded than the teachers themselves and there is no need to teach them - they are able to master electronic gadgets by themselves, and finding information needed is not a huge problem which they can do without teachers' help. The result is that students are not even taught to type in a blind way - one of the skills all western people master while being at school.

Unfortunately, in Ukraine, despite the urgent requirements of the time, media education is still fragmented and is implemented sporadically, and there is no integration of the efforts of teachers-innovators into a unified effective system of media education which is to play an indispensable role in creating civil society. Studying and analysing the experience of more advanced countries in the area of media education, means and ways of making media education really effective, not just one more subject for pro forma which school and university students do not consider interesting and useful, should become the focus of future research and discussions.

Definitely, in Ukraine, media education is on the agenda. It should be paid utmost attention to make it more effective, with developed patriotism and democratic values being the goal of it - to teach "student democratic citizenship skills in a complex, technological world" [39, p.1]. Media literacy education can and should provide people with "the habits of inquiry and skills of expression they need to be critical thinkers, effective communicators, and active citizens in today's world" [31, p. 21].

\section{ЛИТЕРАТУРА}

1. Aufderheide, P. Media Literacy: A report of the national leadership conference on media literacy. Washington, DC: the Aspen Institute, $1993.37 \mathrm{p}$.

2. Buckingham, D. Media education in the UK: Moving beyond protectionism// Journal of Communication, 1998.48(1). P. 33-42.

3. Buckingham, D. After the Death of Childhood: Growing Up in the Age of Electronic Media. Cambridge: Polity Press, 2000. 245p.

4. Buckinnham, D. Digital Media Literacies: rethinking media education in the age of the Internet// Research in Comparative and International Education, Volume 2, Number 1, 2007. P. 43-55.

5. Castells, M. The Internet Galaxy: Reflections on the internet, business, and society. Oxford: Oxford University Press, 2002. 293 p.

6. Christ, W. G., and Potter, W. J. Media literacy, media education, and the academy//Journal of Communication, 1998. 48(1). P. 5-15.

7. Fedorov, A. Media Education and media Literacy: Experts' Opinion//[http://www.europeanmediaculture.org/fileadmin/bibliothek/e nglish/fedorov_experts/fedorov_experts.pdf [3.07.2008]

8. Frau-Meigs, D. (Ed.) Media Education. A Kit for Teachers, Students, Parents and Professionals. UNESCO, 2006. 185 p.

9. Hasebrink, U., Livingstone, S. and Haddon, L. (Eds.) Comparing Children's Online Opportunities and Risks Across Europe: Crossnational Comparisons for EU Kids Online. London: EU Kids Online 2008. 109 p.

10. Hobbs, R. The seven great debates in the media literacy movement// Journal of Communication, 1998. 48(1). P. 6-32.

11. Hobbs, R. Theory and Practice of Media Literacy. Course Syllabus// Temple University School of Communications and Theater. Department of Broadcasting, Telecommunication and Mass Media, Fall, 2007. [https://mediaeducationlab.com/sites/default/files/Theory_and_Pra ctice_ML_Syllabus_0.pdf]. 9 p.

12. Implementation of media education and media literacy courses in secondary schools in Ukraine//Analytical Report on the Results of the Complex Study conducted during 2014-2016, commissioned by Ukrainian Media Project (U-Media Program) implemented by Internews Network [https://www.slideshare.net/umedia/mediaeducation-in-ukrainian-schools-analitycal-report-englishtranslation-2016]. $49 \mathrm{p}$.

13. Jackson, R. Never Work Harder Than Your Students \& Other Principles of Great Teaching. Alexandria, Virginia: USA ASCD, 2009. 249 p.

14. Kellner, D. New Media and New Literacies: Reconstructing Education for the New Millennium. 2002. [http://www.gseis.ucla.edu/faculty/kellner/]. 18 p.

15. Kintgen, E. R., Kroll, B. M., and Rose, M. (Eds.) Perspectives on Literacy. Carbondale, Ill: Southern Illinois University Press, 1988. $475 \mathrm{p}$.

16. Kubey R. W. Obstacles to the development of Media Education in

the United States// Journal of Communication, 1998. Vol. 48, \#1. P.1-10.

17. Kubey R. W. Media Literacy in the Information Age : Current Perspectives New Brunswick, London : Transaction Publishers, $2001.508 \mathrm{p}$.

18. Lievrouw, L., and Livingstone, S. The social shaping and consequences of ICTs// L. L. Lievrouw, S. Livingstone (Ed.), Handbook of New Media: Social Shaping and Consequences of ICTs. Updated Student Edition, 2006. London: Sage, 2006. P. 1-15.

19. Levingstone, S. LSE Research Online. Media literacy and the challenge of new information and communication technologies// Communication review, 1 (7), 2004. P. 3-14. Cit. ex: [http://eprints.lse.ac.uk/1017].

20. Marchis, I., Ciascai, L., and Costa, V. Intercultural and Media Education in Teaching Practice. An Example of Good Practice// Acta Didactica Napocensia, 2008. Vol.1, Number 2. P. 69-75.

21. Masterman, L. Teaching the Media. Routledge: Taylor \& Francis Group, e-Library, 2005. 368 p.

22. McMillan, S. Exploring Models of Interactivity from Multiple Research Traditions: Users, Documents, and Systems// L. Lievrouw \& S. Livingstone (Eds.), The Handbook of New Media. London: Sage Publications, 2002. P. 163-182.

23. Media Education in Four EU countries, Common problems and possible solution// This report was produced with support from Mediawijzer.net.Copyright (C) 2013 Stichting Mijn Kind Online, Kennisnet, Netherlands, 2013. [https://www.mediawijzer.net/wpcontent/uploads/sites/6/2013/10/rapport_media_onderwijs_ EU.pdf]. 47 p.

24. Media Education in 12 European Countries. A Comparative Study of Teaching Media in Mother Tongue Education in Secondary Schools// Research report from the Euromedia Project, coordinated by Andrew Hart at the Media Education Centre at the University of Southampton, U.K. Co-ordination of the publication project by Daniel Süss, University of Applied Sciences Zurich, School of Applied Psychology and Swiss Federal Institute of Technology ZurichE-Collection of the Swiss Federal Institute of Technology Zurich, 2002. - $158 \mathrm{c}$.

25. Newhagen, J. E., and Rafaeli, S. Why communication researchers should study the internet: a dialogue// Journal of Communication, 1996. 46(1). P. 4-13.

26. Paris Agenda or 12 Recommendations for Media Education [https://www.diplomatie.gouv.fr/IMG/pdf/Parisagendafin_en.pdf].

27. Parola, A. and Ranieri, M. The Practice of Media Education: International Research on Six European Countries// The National Association for Media Literacy Education's Journal of Media Literacy Education, 2011. 3:2 P. 90-100.

28. Potter W. J. Media Literacy. Thousand Oaks. London: Sage Publication, $2001.423 \mathrm{p}$. 
29. Recommendation of the European Parliament and of the Council of 18 December 2006 on Key Competences for Lifelong Learning (2006/962/EC)

30. Reding V. Press release IP/06/1326, Brussels, 6 October 2006. [http://europa.eu/rapid/press-release_IP-06-

1326_en.htm?locale=en].

31. Rogow, F. Ask, Don't Tell: Pedagogy for Media Literacy Education in the Next Decade// Journal of Media Literacy Education, 2011. 3:1. P. 16-22.

32. Rowe, D. 'Contemporary Media Education: Ideas for Overcoming the Perils of Popularity and the Theory-Practice Split'// Journal of Media Practice, 2004. 5(1). P. 43-58. [http://web.ebscohost.com/ehost/detail?vid=3\&hid=19\&sid=82759 $7 \mathrm{db}-\mathrm{b} 4 \mathrm{c} 0-414 \mathrm{e}-$

8246336df6092582\%40sessionmgr15\&bdata=JnNpdGU9ZWhvc 3QtbGl2ZSZzY29wZT1zaXRl\#db=vth\&AN=15445257].

33. Sefton-Green, J. (Ed.). Young People, Creativity and New Technologies: The challenge of digital arts. London: Routledge, 2008. 163p.

34. Staksrud, E., Livingstone, S., Haddon, L., and Ólafsson, K. What do we know about children's use of online technologies?: a report on data availability and research gaps in Europe (2009), $2^{\text {nd }}$ ed. 2012. EU Kids Online. 272 p.

35. Study on Assessment Criteria for Media Literacy Levels. A comprehensive view of the concept of media literacy and an understanding of how media literacy levels in Europe should be assessed. For the European Commission. Final report. Brussels, October, 2009, [http://ec.europa.eu/assets/eac/ culture/library/studies/literacy-criteria-report_en.pdf]. 92 p.

36. Study on Assessment Criteria for Media Literacy Levels, Testing and Refining Criteria to Assess Media Literacy Levels in Europe, Final Report, April 2011. Commissioned by the European Commission Directorate-General for Information Society and Media Media Literacy Unit CEuropean Commission, SMART 2010/0006 O.J. 5/12/2009 2009/S235-3355589). [https://eavi.eu/wpcontent/uploads/2017/08/study testing and refi ning $\mathrm{ml}$ levels in europe.pdf]. $236 \mathrm{p}$.

37. Study on the Current Trends and Approaches to Media Literacy in Europe [http://ec.europa.eu/assets/eac/culture/library/studies/literacytrends-report_en.pdf]. $141 \mathrm{p}$.

38. The European Charter of Media Literacy [http://www.euromedialiteracy.eu/index.php?Pg=charter].http://w ww.europarl.europa.eu/sides/getDoc.do?pubRef=//EP//TEXT+TA+P6-TA-2008-0598+0+DOC+XML+V0//EN].

39. Tyner, K. (1991). The Media Education Elephant. Cit. ex: [http://www.medialit.org/reading-room/media-education-elephant]. $-6 \mathrm{p}$.

40. Концепція впровадження медіаосвіти в Україні (нова редак$\begin{array}{lllll}\text { ція). } & 24 & \text { квітня } & 2016 & \text { p. }\end{array}$ http://osvita.mediasapiens.ua/mediaprosvita/mediaosvita/kontseptsi ya_vprovadzhennya_mediaosviti_v_ukraini_nova_redaktsiya/.11c.

41. Медіаосвіта та медіаграмотність: короткий огляд / В. Іванов., О. Волошенюк., Л. Кульчинська та ін. - 2-ге вид., стер. - К.: АУП, ЦВП, 2012. - 58 с.

42. Медіаосвіта та медіаграмотність: підручник / Ред.-упор. В. Ф. Іванов, О. В. Волошенюк; За науковою редакцією В. В. Різуна. — Київ: Центр вільної преси, 2012. — 352 с.

43. Найдьонова Л. А. Перспективи розвитку медіаосвіти в контексті болонського процесу: процесуальна модель медіакультури /Л. А. Найдьонова // Болонський процес і вища освіта Україні та Свропі: проблеми й перспективи. - К., 2007. - С. $162-168$.

44. Наукові записки Тернопільського національного педагогічного університету імені Володимира Гнатюка. Серія: Педагогіка. Теоретичні і методичні засади медіаосвіти. - 2013. - № 3. $176 \mathrm{c}$.

45. Сагайдак Г.В. Медіаосвіта у навчально-виховному процесі початкової школи.

[http://compi.com.ua/mediaosvita-u-navchaleno-vihovnomu-procesipochatkovoyi-shkoli.html]. $10 \mathrm{c}$.

46. Сокологорская Д. Функциональная неграмотность. 30 апреля 2015. [https://syg.ma/@dariasokologhorskaya/funktsionalnaianieghramotnost].

47. Федоров О. Медіаосвіта та медіакритика в контексті підготовки майбутніх педагогів / О. Федоров // Вища освіта України. - 2014. - № 4. - С. 59-70. - Режим доступу: http://nbuv.gov.ua/UJRN/vou_2014_4_11

\section{REFERENCES}

40 Concept of Media Education Implementation in Ukraine (New Version), 24 April, 2016 . http://osvita.mediasapiens.ua /mediaprosvita/mediaosvita/kontseptsiya_vprovadzhennya_mediao sviti_v_ukraini_nova_redaktsiya/. $11 \mathrm{p}$.

41 Media Education and Media Literacy; In a Nutshell// V. Ivanov, O. Volosheniuk, L. Kulchynska, and others. 2d ed. Kyiv: Ukrainian Press Academy, 2012. 58 p.

42 Media Education and Media Literacy: Textbook// Ed. V.V. Rizun. Kyiv: Free Press Centre. 2012.352 p.

43 Neydionova, L.A. Prospects of Media Education Development in Bologna Process Context: Process Model of Media Culture// Bologna Process and Higher Education in Ukraine and Europe: Problems and Prospects. Kyiv, 2007. P. 162-168.

44 Research Papers of Volodymyr Gnatiuk Ternopil National Pedagogical University. Pedagogy. Theoretical and Methodological Foundation of Media Education, 2013. № 3. 176 c.

45 Sagaydak, G.V. Mediaosvita at Primary School. [http://compi.com.ua/mediaosvita-u-navchaleno-vihovnomuprocesi-pochatkovoyi-shkoli.html]. $10 \mathrm{c}$

46 Sokologorskaya, D. Functional Illiteracy. 30April, 2015. https://syg.ma/@daria-sokologhorskaya/funktsionalnaianieghramotnost

47 Fedorov, O. Media Education and Media Critisism in the Context of Teachers' Education// Higher Education In Ukraine, 2014. \# 4. P.. 59-70. http://nbuv.gov.ua/UJRN/vou_2014_4_11.

\section{Медіа освіта: Завдання для України}

\section{О. А. Борисенко}

Аннотация. Появление новых средств массовой информации, компьютеризация всех сфер жизни общества - бизнеса, образования, культуры - превращает медиа грамотность в наиболее востребованное умение для современного человека. Несмотря на насущную необходимость владения медиа грамотностью и ее ведущую роль в создании гражданского общества, в Украине медиа образование фрагментарно, эпизодично, неэффективно. Изучение опыта более передовых в области медиа грамотности западных стран может быть полезным для украинских педагогов.

Ключевые слова: Информачия, компьютерная грамотность, медиа грамотность, медиа образование, невосприимчивость к пропаганде, предвзятая информачия, пропаганда. 